\title{
School Lunch Programs in Israel, Past and Present
}

\author{
Ronit Endevelt
}

\section{Introduction}

Over the last two centuries, the transition from a rural, agricultural society to an urban, industrial society has caused a shortage in many foods that had once been available in the villages, leading to deficiencies in essential nutrients. Nations worldwide have since faced the need to establish programs in order to feed those who no longer have ready access to the fruits of the land, in particular children.

Part of this need has been met by lunch programs. Many countries throughout the industrialized West have created programs of various sorts. Some aim only at feeding the children, while others also seek to teach nutrition. Such efforts have also been undertaken in Israel, beginning in the era of the British Mandate, but were ended in the 1970s as rising prosperity led the Israeli government to conclude that a rich country had no need for a program to feed the poor. The decision was not without its costs, including a widening gap between the various levels of society and a shorter school day that forced many mothers to work just part time. However, in 2005, the Knesset (the Israeli parliament) approved a trial lunch program in response to a survey that revealed a significant need for enhanced nutrition among the poorer students in Israel's schools. An understanding of earlier lunch programs should contribute to successful implementation of this trial.

\section{The Beginning}

Concerns for the nutrition of the Jewish population of Palestine came to the fore at the beginning of the $20^{\text {th }}$ century. They first found expression at the end of 1913, when a Swiss visitor, Theresa Dreyfus, with the aid of the "Dutch Clark Organization," founded two soup kitchens in Jerusalem. The Joint Council on Accreditation of Healthcare Organizations also contributed to the enterprise. At the same time, an American pioneer, Nathan Strauss, founded another group of soup kitchens in Jerusalem. Both programs served soup and bread as part of their outreach to the 
poor. Children and pregnant women could also get a glass of milk. A small fee was charged for the meal, but those who could not pay received it for free. The soup kitchens remained in operation until April 1933, ${ }^{12}$ when they were forced to close because of financial difficulties.

After the First World War, a few kindergarten teachers in Jerusalem came to the realization that their pupils could not concentrate and learn effectively because they were constantly hungry. These teachers started cooking lunches for the children. Financial assistance came from the children's parents and from the orphans' fund. The American Zionist Henrietta Szold helped to collect money for this lunch program. ${ }^{3}$ These efforts formed the foundation for the lunch program in schools that started a few years later.

\section{The School Lunch Program in Palestine and Israel, 1921-1970}

In December 1921, the manager of one of the girls' schools in eastern Jerusalem initiated a school lunch program with the aid of Henrietta Szold. This was followed in 1923 by the Penny Lunch Program in Jerusalem, which was funded largely by pennies that Jewish children in America gave from their Hanukah money, though parents also helped. At a later stage, other donors contributed, including the Hadassah Women's Organization, but the name "Penny Lunches" remained. The program, like the other school lunch programs that had preceded it, was based on the understanding that children cannot study without proper nutrition. As Henrietta Szold told her friends in the Zionist organization: "In the lunch program, one could see girls for whom it was the first time to sit on a chair in front of a table with a fork and a knife and eat."

These small initiatives spread throughout Palestine, and soon school lunches were being organized on a nationwide basis. Henrietta Szold established a management team and nominated a brilliant dietitian, named Sara Bavly, as the head of the program. Together they established rules for the program, found economic resources, and built core knowledge in nutrition among teachers in the schools.

1 Bavly, Sara, "Report on the Hadassah/Vaad Leumi school luncheons project during the period October 1st 1944-September 30th 1945", The Zionist Archive, Z"A J/1/7741.

2 Bavly, Sara, Letter to Dr. Catzenelson on parents' guldens in the school kitchen, The Zionist Archive, A"Z 1946/3/25 J/1/7741.

3 Young Hadassah was an organization of young Jewish women that was founded in November 1920. Its goals were to help in the development of Israel through donations and to encourage young Jewish men and women to understand the importance of building a Jewish nation in Palestine. Henrietta Szold wrote in a letter to the members of Young Hadassah: "Let's accept our young women as teachers and mothers through feeding the young generation in our way." Hed Hadassah Sivan Tamuz TS"Z (1936), pp. 1-2.

4 Rubin Shchory Zipora, "Hadassah Educational Institute in the Mandate Times," Ph.D. dissertation, Ben-Gurion University (1998), pp. 178-212. 
Eventually, a third of the schools in Israel joined in the effort ${ }^{5}$. At that time, the importance of the food calorie resources (protein, carbohydrates, and fat) was already known, and during the 1930s-1940s interest in vitamins grew as well. Thus, the lunch programs could be used as a means for providing valuable nutrition skills for the children and families in addition to feeding the poor children. ${ }^{6}$ This was a revolutionary idea of implementing a central feeding program through a lunch program and was based on a new understanding of the importance of nutrition and social responsibility. Such programs adopted by other Western and developing countries have encouraged school enrolment and attendance and improved school performance and cognitive development. ${ }^{78}$ Other means to equalize the population especially the children and infants were laws for free education that were established later on. In 1949, as in many other modern countries, Public education was generally available to all. In most countries, it was compulsory for children to attend school up to a certain age. ${ }^{9}$ Another social mean that was used in Israel as in other countries at-that time was, subsidizing some of the foods, and creating a food basket for all, and fortifying some of the foods with nutritional vitamins. Those fortifications were based on research that was done in the 30s and 40s in Israel. ${ }^{10}{ }^{11}$

Photo 1. Lunch program in a boys' school in Jerusalem in 1936 (private archive of Sara Bavly).

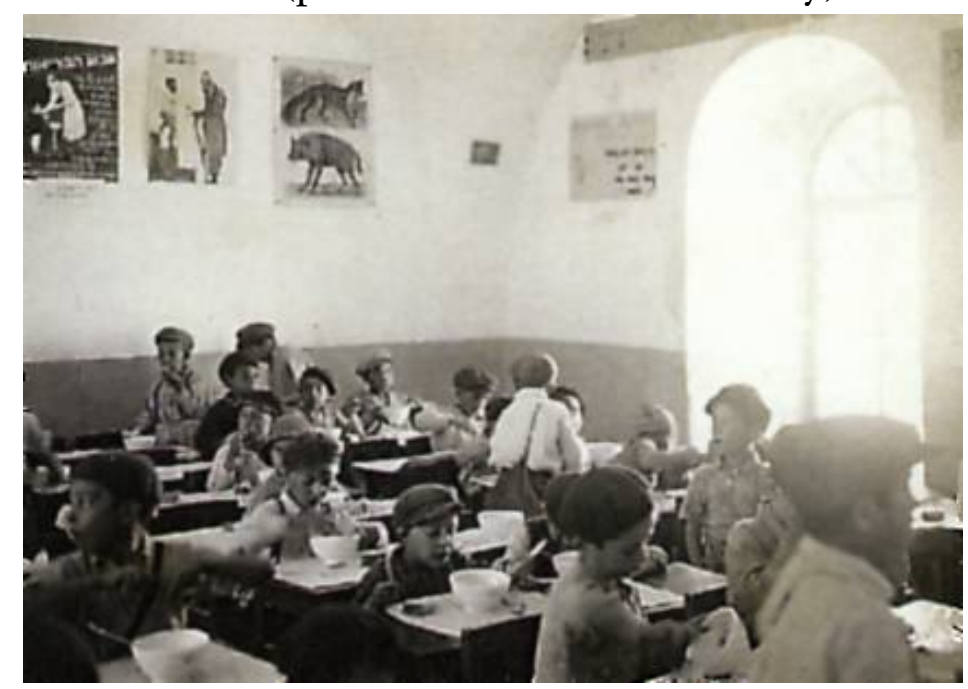

5 Szold, Henrietta, A letter that was sent to the Hadassah in New York about the welfare organizations in Palestine, 9/6/1924, The Zionist Archive, Z"A/A/125/638.

6 Rosenfeld, Louis, "Vitamine-vitamin. The early years of discovery" Clinical Chemistry, (1997) 43:4, 680-685.

7 Feeman, H. E. et al., "Nutrition and cognitive development among rural Guatemalan children," American Journal of Public Health. 70 (1980), pp. 1277-1285.

8 Jamison, D. T., "Child malnutrition and school performance in China", Journal of Development Economics. 20 (1986), pp. 299-309.

9 http://en.wikipedia.org/wiki/Public education (Accessed April 2, 2007).

10 Sadow E., "Outline of Summary of Palestine," January 1927 to May 1927, The Zionist Archive, j /113/83.

11 Economic Advisory Council, Committee on Nutrition in the Colonial Empire, First Report, 1939, London, p. 13, The Zionist Archive, j /113/83. 


\section{Education as part of the lunch program}

The goals of the lunch programs were the elimination of hunger, the promotion of unity, especially among children, under an Israeli flag, and the creation of a new, strong Jewish people, different from those in other countries. The lunch programs were used as a vehicle to educate the children on nutrition and healthy habits in the hope that the children, in turn, would introduce these ideas to their parents, thereby reducing the cultural differences among the immigrants in Palestine.

The proponents of school lunches espoused a revolutionary educational theory that then dominated Palestine, namely "the working learning idea," which stated that "you have to work in order to understand and know." Hence, the children were taught to cook their own lunches, and they also learned how to buy nutritious food economically. Moreover, their lessons included other aspects of home economics as well. ${ }^{12}$ The kitchens also served as teaching kitchens for mothers and older women at night. ${ }^{13}$

The lunch program had another benefit as well: feeding the children at school during the middle of the day allowed for a longer study day. After the school lunch program came to an end in the 1970s, elementary schools, in particular, adopted shorter hours so that pupils could go home to eat sooner.

Photo 2. Boys preparing food as a part of nutritional practical education at a school in Jerusalem in 1938 (private archive of Sara Bavly).

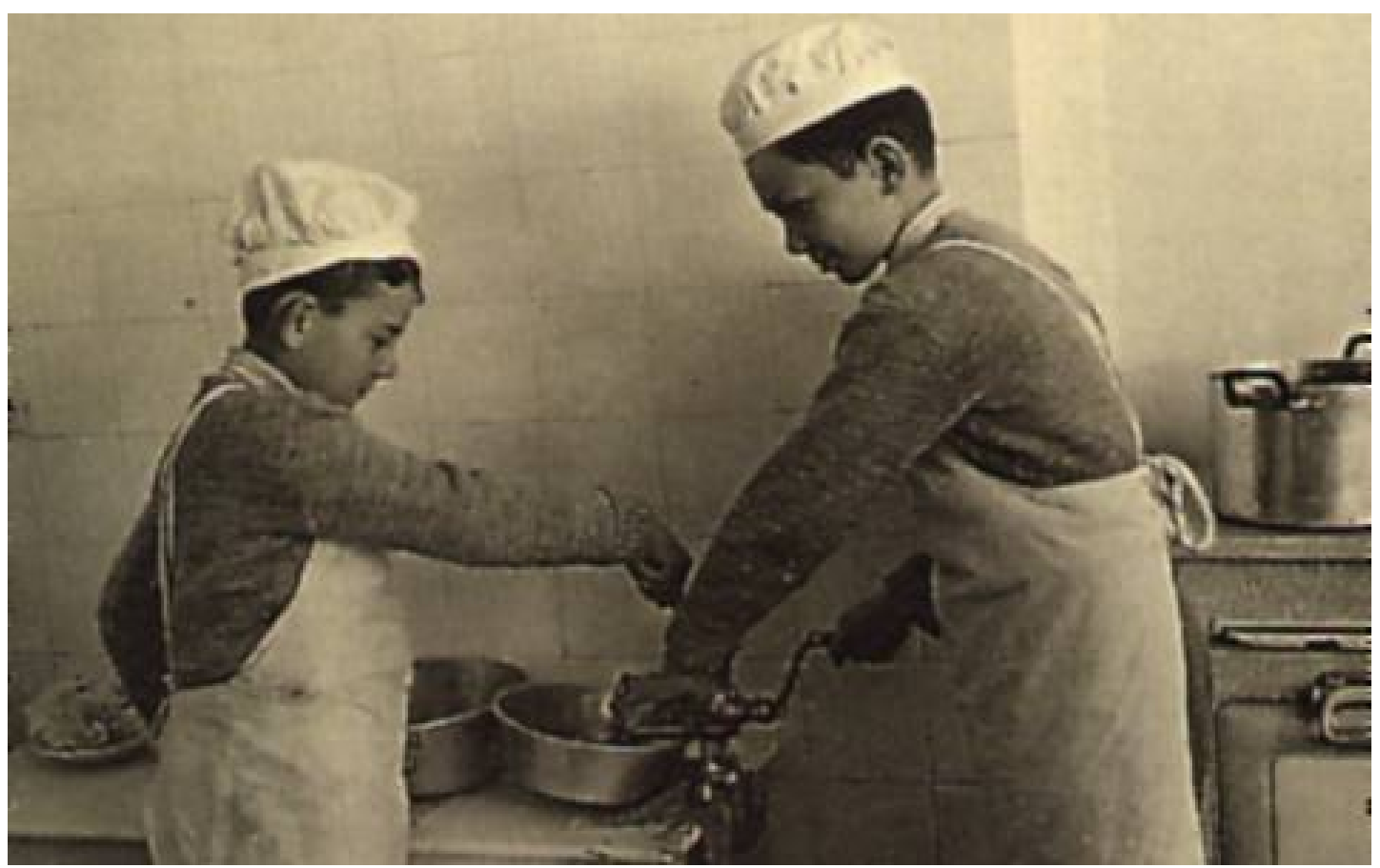

12 Szold, Henrietta, A letter that was sent to the Hadassah in New York about the welfare organizations in Palestine, 2/6/1926, The Zionist Archive, Z"A/A/125/638.

13 Szold, Henrietta, Letter to Miss Julliet N. Benjamin about the management of the school luncheons, 12/5/1929, private archive of Sara Bavly. 


\section{Equality in the Lunch Program}

The lunch program did not distinguish between religious or non-religious children, or even in theory between girls or boys. However, although both sexes participated equally in food preparation, the ancillary activities did differ. The girls studied other topics in home economics, and the boys learned either farming or other skills suitable for urban life.

The program was based on an equal investment, with each pupil having to prepare lunch for 10 other students. Students served for five days at a time, once every two months. Those who were serving their peers were involved in choosing, preparing, and serving the food, as well as washing the dishes. They were required to arrive at school by 7:30 a.m. and have the food ready by 10:30 a.m., though lunch was not served until noon. At 12:30, the children met with their teacher and discussed the recipes and the food values of the day.

Lunch programs were most successful in poorer neighborhoods that participated in the program as part of the school concept. In addition, the programs worked best in schools with fewer than 150 students, as larger schools had to get some of their food from outside caterers. ${ }^{14} 151617$

Photo 3. Children serving milk to the pupils in Jerusalem in 1938 (private archive of Sara Bavly).

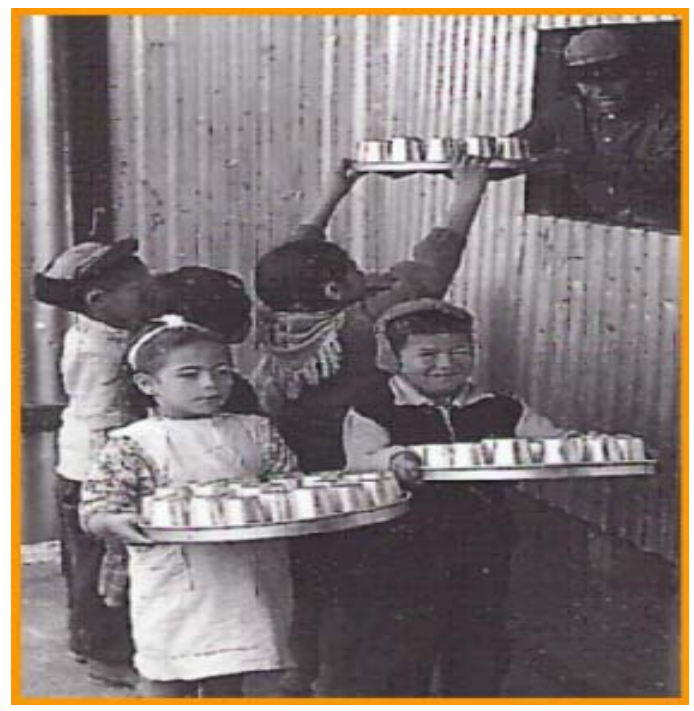

14 Report on a study of school luncheons of Jerusalem, Haifa, and Safad made from January to March 1927, The Zionist Archive, Z”A/A/125/638, New York, File 321.

15 Cohen, E., "Report on the penny school luncheons fund," 1927, private archive of Sara Bavly.

16 Chaim Yassky, "Health Welfare in Palestine," Hadassah News Letter (June 1932), Hadassah Archive in New York, RG=5, Box 2, File 9b H.

17 "Memorandum, Joint Distribution Committee \& Pekude Ve Amarkale Amsterdam," May 28, 1924, JDC (Joint Archives in N.Y.). 


\section{Teaching Teachers}

Until 1930, it was difficult to find good teachers who knew how to teach and how to cook. The nutrition teachers worked for short periods, mostly for a few months at a time, and they were often fired because of a lack of professionalism. During summer vacations and holidays, they received no salary so that the lunch program could save money. One of Sara Bavly's first initiatives was to provide her teachers with decent nutritional education. She also gave the nutrition teachers employment rights that were equal to those of other teachers at the time. ${ }^{18}{ }^{19}{ }^{20}{ }^{21}$ Her successes enabled her to convince the Tel Aviv school managers to join the program, rather than establishing their own lunch program provided by a caterer.

Teacher education was built up gradually, starting with a single course of a few months at the beginning of the 1930s. A two-year program at the pedagogical college of nutrition debuted in 1953. After later extending the program to three years, ${ }^{22}$ the college continued to teach nutrition until the beginning of the 1990s. At the end of the 1980s, however, the Ministry of Education decided that there was no need for nutrition and home economics teachers in school and fired most of them. 2324252627

18 Sara Bavly (Brumberg) was a young nutritionist and Zionist who came from the Netherlands to Palestine in 1926. She first taught nutrition in a village called Nahallal in the Israel Valley. Later, in Jerusalem, she became the manager of the nutrition services in the Hadassah hospitals. She ran the lunch program from 1930 until 1960. She also initiated and managed a college for nutrition education and nutrition teachers in 1952 with the help of donations from the United States.

19 Rothschild Hospital - Transfer of maternity ward to health center, 6/8/1933, Hadassah Archive in New York, RG=2, Box 32, Folder 8.

20 Richer, N., "Roots or horizons of the Israeli student in Israel in the years 1889-1933," Katedra (1983): 55-96.

21 The Hebrew Encyclopedia, Vol. 17, p. 347.

22 Brumberg, Sara, "Nutrition and Health," The Palestine Post (9/5/1939), private archive of Sara Bavly.

23 "Nutrition and cooking for boys," July 1934, Hadassah Archive in New York RG=5, Box 2, File 9b.

24 Bavly, Sara, "Lunch system in Palestine teaches cooking," The Nation's Schools 14:1 (July 1934), private archive of Sara Bavly.

25 Bavly, Sara, "Report to the Labor Office of the League of Nations: Methods of amelioration of nutrition among the working class in Palestine" (April 23, 1936), private archive.

26 Bavly, Sara, "Report of the work of Hadassah school luncheons, October 1936 to September 1937" (n.d.), The Zionist Archive, Z"A J/1/3386.

27 Rubin Shchory Zipora, "The cafeteria: the feeding program of Hadassah in the Hebrew schools," Katedra 92 (June 1999), 129. 


\section{The Lunch Program During the Summer - Day Camps}

Many pupils obtained at least a third of their nutrition from the lunch program, so the summer recess posed a major nutritional challenge. In response, the management of the lunch program decided to widen the program to supply food to day camps during the summer. ${ }^{28}{ }^{29}$ Since these day camps were located in the schools in Tel Aviv, Haifa, Jerusalem, and Tiberius, the nutrition teachers were used to cook the food. The summer programs were successful, as it was reported that children gained up to two kilograms during the course of the day camps.

\section{The Influence of Lunch Programs in Other Countries}

At the time, lunch programs were a very common means of feeding children in the Western world, though many kinds of programs were in use. In the United States, for example, most of the programs were based on cooking in a central kitchen because of the large numbers of students who needed to be fed. The children ate in a cafeteria, choosing from a variety of food options. In such a setting, nutrition and home economics were taught as minor topics, as the children received little direct experience.

Schools in England began teaching nutritional skills in the 1930s, but only poor pupils received free food. According to Thomas McKeown (a professor in social medicine), "population growth was due primarily to a decline in mortality from infectious disease". This decline was driven by improved economic conditions that attended the Industrial Revolution, which provided the basis for rising standards of living and, most importantly, enhanced nutritional status by different means, including lunch programs that bolstered resistance to disease". ${ }^{31}$ Bernard Harris tries to make a qualified defense of McKeown's hypothesis by saying that nutrition and economic conditions should be regarded as only one of a battery of factors, often interacting, which played a key role in Britain's transition from a high to a low rate of mortality ${ }^{32}$. The dominating view from the critics has been that nutrition did not contribute to the secular decline in mortality in Western Europe during the $19^{\text {th }}$ century. Particularly the importance of the sanitary revolution in urban areas has been highlighted, but also factors such as the introduction of

28 A protocol of a meeting of the National Committee for Feeding Children, May 30, 1945, The Zionist Archive, Z"A J/1/7741.

29 Bavly, Sara, "Report on feeding in the summer day camp, organized throughout the country, and the contribution of the school luncheons of Hadassah in the project," The Zionist Archive, Z"A J/1/3386.

30 Day camp circular (1964), Israeli government archive, 1103/007.

31 Colgrove J., "The McKeown Thesis: A Historical Controversy and Its Enduring Influence," American Journal of Public Health, 92:5 (2002), 725-729.

32 Harris Bernard, "Public Health, Nutrition, and the Decline of Mortality: The McKeown Thesis Revisited," Social History of Medicine, 17 (2004), 379-407. 
smallpox vaccination. Regarding the importance of curative medicine, however, most scholars have accepted McKeown's view that it did not play a major role before the introduction of chemotherapy in the 1930s and particularly with the introduction of antibiotics in the $1940 \mathrm{~s}^{33}$.

In Germany, some of the children participated in lunch programs and had to prepare the food by themselves. Research from later years also shows a use of the canteen system in eastern Germany, where most of the children received lunch at school $^{34}$.

Palestine thus employed a more modern and innovative approach to nutritional education than other, wealthier nations, using a model that combined the strengths of the English, German, and American systems. ${ }^{35}$ This combination was a result of the varied nutritional and administrative origins of the managers of the lunch program, who were part of the melting pot that was typical to the beginning years of the country. For example, Sara Bavly, who was the manager of the lunch program, received her bachelor's degree in Holland and her master's degree done in Boston school of home economics in the United States. Her education in both countries and her experience under the British Mandate allowed her to combine facets of the three systems into the lunch program in Palestine. ${ }^{36}$

\section{The Widening of the Lunch Program During the Second World War}

By the start of the Second World War, the lunch program had spread throughout much of the country. The scope of the program in 1941 is illustrated in Table 1. By 1944, the lunch program had extended even farther to the smaller cities and into the countryside, employing 70 nutrition teachers on a full-time basis.

As the Jewish communities in Palestine began to hear of the terrible events of the Holocaust, the school lunch program became part of the Zionist effort to create

33 Bernard Harris, (2004,) 379-407.

34 Pazola Z., [School feeding programs for children and adolescents in East Germany (personal observations)], Problemy Medycyny Wieku Rozwojowego, 11:1 (1982), 132-139.

35 "Nourishment for the child," 13/4/1944, The Zionist Archive, Z"A, J/1/8213.

36 Bavly, Sara, "Curriculum Vita of Sara Bavly, 1960," private archive of Sara Bavly.

37 Bavly, Sara, "A survey of the development and aims of the Hadassah school luncheons, October 1940," private archive of Sara Bavly.

38 Bavly, Sar, "A report on the work of the Hadassah luncheons for the period October 1 1943-September 30 1943," April 1944, private archive.

39 Bavly, Sara, Memo on the use of milk powder for school luncheons, 11/4/1944, The Zionist Archive, Z"A, J/ 1/ 8213.

40 "A memory of a conversation between the health center and the lunch fund of Hadassah," The Zionist Archives, 1945/8/5 J 8213/1/.

41 Bavly, Sara, "Report on the Hadassah/Vaad Leumi school luncheons project during the period October 1st 1944-September 30th 1945", The Zionist Archives J/1/7741. 
powerful soldiers, or "Zebras" Jews who were strong enough to fight for their freedom. ${ }^{42}{ }^{43}$

\section{A Cooperative Venture}

In 1939, Sara Bavly established cooperation between Hadassah's lunch fund and the social work division of the Palestine National Committee. The social work division handled the collection of money and checked each family's ability to pay. Families were separated into three categories: Group 1 paid only 5 million per day, Group 2 paid between 5 and 10 mill a day, and Group 3 paid the real price of the meal. ${ }^{44}$ Schools received additional funding according to the number of children in each group, with funds coming from Hadassah and other national organizations. Although the program did make an attempt to treat all the children as equals, the children knew who paid and who did not, so the gap between different classes remained.

Table 1. The spread of the lunch program in Palestine (Israel) in $1941 .^{41}$

\begin{tabular}{cccccc}
\hline $\begin{array}{c}\text { Location of } \\
\text { lunch } \\
\text { program }\end{array}$ & $\begin{array}{c}\text { No of schools } \\
\text { where } \\
\text { children } \\
\text { cooked lunch }\end{array}$ & $\begin{array}{c}\text { No. of } \\
\text { institutions }\end{array}$ & Kindergartens & $\begin{array}{c}\text { Central } \\
\text { kitchens }\end{array}$ & $\begin{array}{c}\text { No of } \\
\text { children } \\
\text { receiving } \\
\text { lunch } \\
\text { program }\end{array}$ \\
\hline $\begin{array}{c}\text { Jerusalem } \\
\text { Tel Aviv }\end{array}$ & 16 & 75 & 9 & 1 & 4,760 \\
\hline Haifa & 13 & 95 & 29 & 2 & 8,650 \\
\hline $\begin{array}{c}\text { Villages } \\
\text { Dormitories }\end{array}$ & 25 & 32 & 6 & & 2,438 \\
Food supply & 12 & 10 & 8 & & 7,265 \\
special needs & & & & & 1,772 \\
\hline Sum & 78 & 320 & 52 & 3 & 25,385 \\
\hline
\end{tabular}

\section{Connections Between the Lunch Organization and Other National Organizations}

Fiscally, the nutrition education program faced a complex situation, as Palestine was under British Mandate at the time, the program could not rely on taxes or other government funding to cover its costs. The Mandate government contributed $14 \%$ of the cost and agreed to cover an additional portion if matched by the Jewish population. The mandate government did not agree to pay anything for the lunch

42 A protocol of a meeting of the National Committee on Feeding Children, A"Z 1945/12/26J/1/7741.

43 Yafit, C. Ma., "Feeding children in schools," The Zionist Archives, 1945/12/6 J/1/7741.

44 Yafit, C. Ma., "A memory from a visit in Tel Mond," The Zionist Archive, A"Z 1945/12/19 J/1/7741. 
program in the Arab schools because the Arabs did not give any contribution from their side. The Jewish teachers and administrators initiated a campaign to enlist the support of parents by teaching them about nutrition and thereby obtained a modicum of financial support. Moreover, Henrietta Szold and Sara Bavly were successful in inducing the American Hadassah women to help finance the lunch program. Dr. Bavly also gave lectures to parents on many occasions about the importance of the lunch program in an effort to build support. ${ }^{4}$

Thus, funding for the lunch program's budget came from several sources: Hadassah (30\%); the Mandate government (14\%); the Community Helps Organizations (22\%); women's organizations other than Hadassah (2\%); and parents' payments (32\%). Other organizations gave administrative assistance. The National Council helped with the education of the teachers. Community food committees helped collect money from parents and ensured that the schools had enough food. The Mandate government appointed a supervisor to ensure that all children, both Jewish and Arab, received sufficient nutrition, particularly in those cities with a large Arab population, such as Jaffa, Haifa, and Jerusalem.

\section{An Attempt to Secure Government Funding}

In 1948, Sara Bavly asked the new Israeli government to pass a law financing the lunch program, as was done in England at the time. The government rebuffed this recommendation, so the lunch program perforce continued to depend on contributions and donations. ${ }^{5}$

Municipalities contributed, but the national government provided no financial support. Presumably there were financial constraints, and nutrition and health were not considered priorities by the government, which was preoccupied with other events.

The rise of anti-Semitism in European countries, the growth of Zionism and the national movements brought about waves of Jewish immigration to Israel throughout the first half of the $20^{\text {th }}$ century, reaching a peak after the establishment of the State of Israel with the arrival of 750,000 immigrants from all corners of the earth. Coping with the mass immigration of which the majority arrived penniless,

45 "Women soldiers looking for their future," November 11, 1949, Hadassah archive in New York, RG=5, Box 2, Folder 1 .

46 Valach, Y., "The beginning of the settlement until the country of Israel was established," Atlas Carta for the History of Israel, 2d ed. (Jerusalem: Carta, 1974), 101.

47 "25 years for the lunch fund of Hadassah," Al Hamishmar (March 22, 1949), p. x\$32.

48 Bavly, Sara, "The activities of the Nutrition Department 1955," private archive.

49 Bavly, Sara, "From the nutrition department," Culture and Education 3 (July-August 1955).

50 Bavly, Sara, Short description of the Nutrition Department, September 6, 1959, Israeli government archive, 1717/8.

51 The Office of the State Comptroller-Nutrition Department-the Education Office on the Feeding of Children, March 1960, Israeli government archives. 
presented complex economic and agricultural challenges to the government, including the production and coordinated distribution of sufficient quantities of food to feed the population. Thus, the lunch program was left to survive on donations without any legal backing. ${ }^{52} 53$

\section{The End of the Lunch Program}

The lunch program continued its work until 1970, three years after the "Six Day War." In that time of prosperity, many felt that there was no need for an organized program to feed students. Avraham Reshef, the manager of the nutrition department and the administrator responsible for the lunch program in the Ministry of Health at the time, made the decision to end the lunch program. ${ }^{54} \mathrm{~A}$ few years later, nutrition education was largely eliminated from the schools as well..$^{55}$

\section{A New Beginning}

After more than three decades, the need for some sort of lunch program has once again been recognized. In 2003, of the more than 2,250,000 children in Israel, almost a third was living below the poverty line, (below $50 \%$ of median income available to a family in Israel) and that percentage is increasing. A survey conducted in 2002 by the Ministry of Health and the Joint Council on Accreditation of Healthcare Organizations showed that many children were not enjoying "food security" because of their economic situation. The definition of food security, according to $\mathrm{WHO}$, is "when all people at all times have access to sufficient, safe, nutritious food to maintain a healthy and active life." Commonly, the concept of food security is defined as including both physical and economic access to food that meets people's dietary needs as well as their food preferences. Food security is built on three pillars: food availability having sufficient quantities of food available on a consistent basis; food access having sufficient resources to obtain appropriate foods for a nutritious diet; and food use-appropriate use based on knowledge of basic nutrition and care, as well as adequate water and sanitation. ${ }^{56}$ The inability to feed oneself in secure proper nutrition due to lack of resources and unhealthy eating

52 Reshef, Avraham. et al., "The lunch program's contribution to children's nutrition," Public Health, 19 (1976), 319-328.

53 Guggenheim, K. Abramson, J. H. Perez, E and Reshef, A. "Diet and nutrition of children in selected Jerusalem schools," Israeli Journal of Medical Science 2:3 (May-June 1966), 344-349.

54 Avraham Reshef was the manager of the Nutrition Department in the Health Ministry from 1964 to 1997.

55 Reshef, Avraham, Personal interview, November 29, 2000.

56 http://www.who.int/trade/glossary/story028/en/ (March 31, 2007). 
habits is one of the challenges of the $21^{\text {st }}$ century, with obesity and malnutrition posing a global health threat Indeed, obesity is becoming an epidemic in Israel, as in other Western countries.

In response to that threat, the Knesset (the Israeli Parliament) proposed two new laws in 2004 with the aim of re-introducing school lunch programs. The first, Ruchama Avraham's Feed the Poor proposal, was meant to target only poor children; the second, Yulie Tamir and Eti Livni's Feed All proposal, was more egalitarian. Unfortunately, due mainly to economic and logistic considerations, the Feed the Poor proposal was passed.

In 2004, the Ministry of Social Welfare funded a pilot program in 22 schools. An advisory committee was appointed to make recommendations regarding the program and the menus. ${ }^{58}$ At the present time, hot cooked lunches are being provided at more than 60 elementary schools throughout the country, and there are plans to expand the program to encompass 500 schools with 154,000 pupils.

The Prime Minister's office has nominated a non-profit organization to run the program (the Sakta Rashi Fund). As in the past, funding the program requires the coordination of multiple revenue sources. The central government does subsidize the meals, but parents and municipalities must contribute up to $25 \%$ of the cost.

\section{Conclusions}

Since the beginning of the $20^{\text {th }}$ century, many countries have had lunch programs of various sorts. Recent research conducted in schools in China shows that improving the quality of food and providing education on nutrition can change the behaviour of both children and parents. ${ }^{59}$ Research in the United States indicates that the successful implementation of lunch programs requires not only the collaborative efforts of school administration and staff but also the support of parents, community, and the mass media in fostering healthy eating.

The managers of the new Israeli school lunch program have an opportunity to learn from past experience in order to achieve success in providing both nutrition and nutritional education. Reviving the lunch program without learning from the past would squander this opportunity. Henrietta Szold's initiative and the Penny Lunch Program spread throughout the country with just a few resources, but much

57 Shi-Chang, X. et al., "Creating health-promoting schools in China with a focus on nutrition," Health Promotion International, 19:4 (December 2004), 409-418.

58 In 2004, the Ministry of Social Welfare funded a pilot program in 22 schools. An advisory committee was appointed to make recommendations regarding the program and the menus. The following made up The advisory committee was made up of the following members: Prof. Z. Madar from the agriculture school; Hava Altman from the Nutrition Department in the Health Ministry; Anat Levi, a children's nutritionist; Dr. A. Stark, a research nutritionist; and. Dr. R. Endevelt, the head of the nutrition unit in the second biggest HMO in Israel.

59 Cho, H. and Nadow, M. Z. "Understanding barriers to implementing quality lunch and nutrition education," Journal of Community Health 29:5 (October 2004), 421-35. 
enthusiasm. Sara Bavly understood the value of a lunch program not just as a means of feeding the poor, but also as a way to bolster both nutritional and general education (since school hours can be longer when children are fed at school).

The goals of the modern school lunch program should likewise be twofold, both nutritional and educational. The new program can benefit those suffering from inadequate nutrition due to poverty, and it can also teach children healthy eating habits at a time when obesity is becoming epidemic. The children of the 1930s and the children of today are not malnourished for the same reasons. Mainly economic reasons were previously responsible for inadequate nutrition, and concern about children being unable to concentrate because they were hungry. There were also big concern to get enough protein and for today, maybe too much concern over animal protein was one of the precursor for obesity. ${ }^{60}$

Nowadays it is also the variety of food choices and the lack of parents' knowledge and authority that lead to poor eating habits: the tempting surroundings, and lace of physical activity. Healthy nutrition is a precondition for a healthy population. Neglecting this issue will lead to serious and costly long-term health problems. Governmental policies should take this into account, ensuring that schools throughout the country participate in providing both nutrition and nutritional education. To do so, it is recommended that the government give full funding for a national lunch and nutrition program so that its benefits are not undermined by the constant need to seek financial support. Obesity is becoming an epidemic in Israel as in other western countries; a country wide lunch and nutrition program may help solve the program.

Ronit Endevelt, is the head dietitian of Maccabi Health Medical Services and a lecturer in Haifa University, Israel. E-mail address: rendevelt@univ.haifa.ac.il.

60 Cannon, G., Nutrition: the new world map. Asia Pacific Journal of Clinical Nutrition, 11 (2002) (suppl.), S480-S497. 